\title{
Dry Mass Accumulation, Nutrients and Decomposition of Cover Plants
}

\author{
Daiane Conceição de Sousa ${ }^{1}$, João Carlos Medeiros ${ }^{2}$, Julian Junio de Jesus Lacerda ${ }^{1}$, Jaqueline Dalla Rosa ${ }^{2}$, \\ Cácio Luiz Boechat ${ }^{1}$, Maria de Nazaré Gomes de Sousa ${ }^{1}$, Paula Caroline Ferreira Rodrigues ${ }^{3}$, \\ Elias Gomes de Oliveira Filho ${ }^{1} \&$ Álvaro Luiz Mafra ${ }^{4}$ \\ ${ }^{1}$ Federal University of Piauí, Campus Professora Cinobelina Elvas (CPCE), Bom Jesus, PI, Brazil \\ ${ }^{2}$ Federal University of South Bahia, Campus Jorge Amado (CJA), Itabuna, BA, Brazil \\ ${ }^{3}$ Department of Agronomy, Federal Rural University of Pernambuco, Recife, PE, Brazil \\ ${ }^{4}$ Santa Catarina State University, Campus UDESC Lages, Lages, SC, Brazil \\ Correspondence: Jaqueline Dalla Rosa, Federal University of South Bahia, campus Jorge Amado (CJA), \\ Formation Center of Science and Agroforestry Technologies, Itabuna, BA, Brazil. E-mail: \\ jaqueline.rosa@ufsb.edu.br
}

Received: December 12, $2018 \quad$ Accepted: February 10, $2019 \quad$ Online Published: April 15, 2019

doi:10.5539/jas.v11n5p152 URL: https://doi.org/10.5539/jas.v11n5p152

The research is part of a project supported by National Council for Scientific and Technological Development-CNPq (Process $\left.N^{\circ} 442506 / 2014-7\right)$.

\begin{abstract}
The use of cover crops is an important strategy for soil management in the Brazilian Cerrado to improve no-tillage (NT) systems. For this, it is necessary know the potential of cover crop species for biomass production, nutrient cycling, and persistence of residues on the soil surface in soils and climatic conditions of this biome. Thus, the experiment was developed to evaluate the agronomic potential of cover crops cultivated on an Oxisol (Latossolo Amarelo) in the Cerrado of Piauí, Brazil. The experiment was conducted from January 2015 to July 2016. The experimental design was in randomized blocks with 11 treatments and four replicates. The treatments consisted of single and intercropped cover species. The evaluations were: dry mass production, nutritional composition of the plants, nutrient accumulation by dry mass produced and decomposition rate of the dry mass produced for each treatment. The higher dry matter production was obtained with Crotalaria juncea, Cajanus cajan (cv. IAC-Fava larga), Pennisetum glaucum and Brachiaria ruziziensis. The lower dry matter production was obtained with Mucuna aterrima, and mix of Crotalaria spectabilis + Pennisetum glaucum. The higher nutrients accumulation in the plants occurred for Cajanus cajan (cv. IAC-Fava larga), Crotalaria juncea and Crotalaria spectabilis. The cover plants studied presented good potential for soil conservation, due to the permanence of residues on the surface, except for Mucuna aterrima and Crotalaria spectabilis.
\end{abstract}

Keywords: nutrient cycling, decomposition rate, no-tillage

\section{Introduction}

The southwest region of Piauí is part of the Brazilian agricultural frontier called MATOPIBA (Maranhão, Tocantins, Piauí and Bahia), which currently is in large agricultural expansion and intensification of land use for the cultivation of grains, fibers, energy materials, perennial crops and irrigated agriculture (Fontana et al., 2016). Despite the great productive potential, many technical-scientific recommendations applied to the soils come from regions with different edaphoclimatic conditions. The region presents a dry season from May to November and a late rainy season. Such climatic characteristics associated with the low water retention by the soils make it impossible or more difficult to carry out a double cropping system in this region.

Soil management practices such as no-tillage (NT), crop rotation and use of cover crops are important techniques which can maintain and/or promote yield gains and soil quality with less environmental impact (Krenchinski et al., 2018; Pavinato et al., 2017). However, these techniques are not adapted to the soil and climate conditions of the Cerrado in south Piauí, with poor results for NT, especially regarding the formation of straw, which is an essential factor for the good performance of this system. Studies with techniques for introducing cover crops capable of promoting high phytomass production and maintaining soil cover rate may favor the expansion of NT. 
Furthermore, they can improve soil quality and the accumulation of nutrients by plants cycling in the region (Berg, 2018).

The use of cover crops in a rotational system with annual crops provides several benefits to the productive system, especially nutrient cycling (Pacheco et al., 2017; Tiecher et al., 2012), protection from raindrop impact, with reduced soil surface degradation (Dalla Rosa et al., 2017) and erosion reduction (Nielsen et al., 2016). It can also increase organic carbon (Ferreira et al., 2016; Sousa et al., 2017), which improves soil physical, chemical and biological properties and mitigates environmental impacts caused by land use (Qu et al., 2016).

Regarding nutrient cycling, the amount of these elements in the plant is proportional to the dry mass produced, varying among species according to the absorption efficiency (Pissinati et al., 2018). However, for the cycling efficiency of the essential elements, there should be synchrony between the nutrient released by the residue of the cover plants and the demand for the crop grown in succession (Barbosa et al., 2015).

In the Cerrado of Piauí, studies with cover crop species are necessary to estimate the accumulation of nutrients associated with plant biomass and the decomposition rate of plant residues and to define the appropriate species to enable NT in the region. Therefore, the aim of this work was to evaluate the dry mass production, nutritional composition and the plant residues decomposition of cover crop species in the Cerrado of Piauí.

\section{Materials and Methods}

The experiment was carried out at Fazenda Tropical in Baixa Grande do Ribeiro, PI. The farm is located at $08^{\circ} 42^{\prime} 54.2^{\prime \prime} \mathrm{S}$ and $45^{\circ} 01^{\prime} 41.4^{\prime \prime} \mathrm{W}$ and $495 \mathrm{~m}$ altitude. The climate of the region is hot and humid (Cwa) with average annual temperature of $26.6^{\circ} \mathrm{C}$ and average rainfall of $945 \mathrm{~mm}$ year ${ }^{-1}$. The rainiest period is concentrated from January to April and the driest is from July to November (Alvares et al., 2013). The soil is characterized as an Oxisol (Yellow Latosol in the Brazilian classification). The soil chemical and granulometric composition before the experiment is described in Table 1.

Table 1. Soil chemical and granulometric composition in the $0-0.20 \mathrm{~m}$ depth layer of the experimental area before the experiment implantation

\begin{tabular}{|c|c|c|c|c|c|c|c|c|c|c|c|}
\hline $\mathrm{pH}$ & $\mathrm{OM}$ & $\mathrm{P}$ & $\mathrm{K}^{+}$ & $\mathrm{Ca}^{2+}$ & $\mathrm{Mg}^{2+}$ & $\mathrm{Al}^{3+}$ & CEC & V & Sand & Silt & Clay \\
\hline & $\mathrm{g} \mathrm{kg}^{-1}$ & $---m$ & $n^{-3}---$ & ---- & $---\mathrm{cr}$ & $\mathrm{dm}^{-3}$ & ---------- & $\%$ & - ----י & $-\mathrm{g} \mathrm{kq}^{-}$ & ----------" \\
\hline 6.0 & 34 & 25.8 & 3.4 & 2.0 & 1.7 & 0.3 & 4.9 & 46.5 & 673 & 71.5 & 255.5 \\
\hline
\end{tabular}

Note. $\mathrm{pH}$ : water $\mathrm{pH}, \mathrm{OM}$ : Organic matter, $\mathrm{P}$ : phosphorus, $\mathrm{K}^{+}$: potassium, $\mathrm{Ca}^{2+}$ : calcium, $\mathrm{Mg}^{2+}$ : magnesium, $\mathrm{Al}^{3+}$ : aluminum, CEC: cation exchange capacity, V: base saturation.

Daily precipitation monitoring was performed with a pluviometer installed in the experimental area (Figure 1).

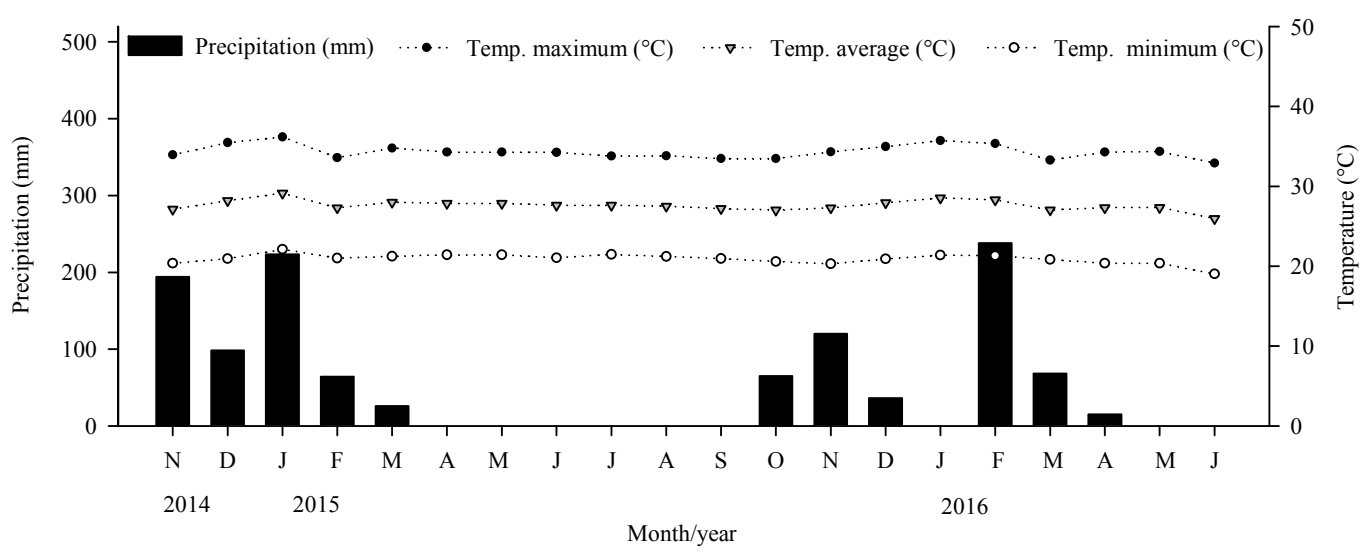

Figure 1. Precipitation accumulated monthly rainfall and recorded temperatures in the experimental area during the study period

In 1990, the experimental area was deforested and cashew was cultivated until 2010. In 2011, cashew crops were eliminated and the soil was tilled for pastures establishment (Urochloa brizantha), which remained in the area until 2013. In 2013/2014 crop season, soybean (cultivar Paragominas RR) was sown on the brachiaria straw. For 
this crop, the soil was tilled with harrow leveler for the incorporation of $2000 \mathrm{~kg} \mathrm{ha}^{-1}$ dolomitic limestone with a neutralizing index of $85 \%$. At soybean sowing, the fertilization was performed with $173.4 \mathrm{~kg} \mathrm{ha}^{-1} \mathrm{~K}_{2} \mathrm{O}(\mathrm{KCl})$, $22.5 \mathrm{~kg} \mathrm{ha}^{-1}$ sulfur (Sulfogran $90 \AA$ ) and $50 \mathrm{~kg} \mathrm{ha}^{-1}$ of $\mathrm{P}_{2} \mathrm{O}_{5}$ (single super phosphate) as recommended by Souza and Lobato (2004).

In January 2015 , the experiment was carried out with a randomized block design with split plots and four replicates. The cover crops species $(12 \mathrm{~m} \times 12 \mathrm{~m})$ were allocated in the main plots, and the time of dry mass evaluation was allocated in the subplots $(1 \mathrm{~m} \times 0.5 \mathrm{~m})$.

The treatments were the single crops: Crotalaria juncea, Crotalaria spectabilis, Crotalaria ochroleuca, Cajanus cajan (cultivar IAPAR 43) Cajanus cajan (cultivar IAC-fava larga), Mucuna aterrima, Brachiaria ruziziensis and Pennisetum glaucum, and the intercropping systems using: Pennisetum glaucum + Crotalaria spectabilis and Pennisetum glaucum + Crotalaria ochroleuca.

Sowing was performed with the incorporation of the seeds by a disc harrow, following the technical recommendations of the company Pirai Sementes.

At 183 days after sowing (DAS), plants were desiccated using two commercial formulations based on potassium glyphosate at $2.0 \mathrm{~L} \mathrm{ha}^{-1}$. Then, flumioxazina ${ }^{\circledR}$-based herbicide was applied at $0.1 \mathrm{~L} \mathrm{ha}^{-1}$.

Before desiccation, aboveground mass was sampled using a $0.5 \mathrm{~m}^{2}$ frame in each plot. Dry mass (DM) was evaluated in an oven at $65{ }^{\circ} \mathrm{C}$ until reaching a constant mass. Afterwards, the plant material was ground in a Wiley mill to determine nutrients content ( $, \mathrm{P}, \mathrm{K}, \mathrm{Ca}, \mathrm{Mg}, \mathrm{Zn}, \mathrm{Fe}$ and $\mathrm{Mn}$ ). $\mathrm{N}$ content was determined by the Kjeldahl method. Nitroperchloric digestion was used for the analysis of the other nutrients, according to the methodology described by Vitti et al. (2002).

The accumulation of nutrients was obtained from the contents in the plant tissue and the amount of dry mass produced by each cover species.

The DM decomposition rate was evaluated at 117, 263 and 314 DAS. All material was collected on the soil surface in an area of $0.5 \mathrm{~m}^{2}$ per plot with four replicates and the material was dried in an oven at $65{ }^{\circ} \mathrm{C}$ until reaching a constant mass. The decomposition rate as a function of time was determined at different times $(0,117$, 263 and 314 days after desiccation) obtaining the percentage of remaining DM on the soil surface. Daily decomposition rates $(k)$ were estimated by regression models proposed by Wieder and Lang (1982). For data adjustment, the first order exponential model proposed by Olson (1963) was applied: $y=a \cdot \exp ^{-k t}$; where, $y=\%$ residue on the soil surface, $t=$ length of stay in days, $a=$ coverage mass at time zero and $k=$ daily decomposition rate. Half-life time $\left(t^{1 / 2}=0.693 / k\right)$ of each species was estimated from the constant values of dry matter decomposition.

The results were submitted to analysis of variance with $\mathrm{F}$ test at $5 \%$ probability. Means were compared by the Scoott-knott's test $(\mathrm{p}<0.05)$ through the statistical program SISVAR $®$ (Ferreira, 2011).

\section{Results and discussion}

There were significant effects of cover plants for nutrient content and sampling time and for the interaction between cover crops and sampling time for DM production (Table 2).

Table 2. Analysis of variance ( $\mathrm{F}$ values) for dry matter and nutrient uptake of different plant cover

\begin{tabular}{|c|c|c|c|c|c|c|c|c|c|}
\hline SV & DM & $\mathrm{N}$ & $\mathrm{P}$ & $\mathrm{K}^{+}$ & $\mathrm{Ca}^{2+}$ & $\mathrm{Mg}^{2+}$ & $\mathrm{Fe}^{3+}$ & $\mathrm{Mn}$ & $\mathrm{Zn}^{2+}$ \\
\hline Block & $0.49^{\mathrm{ns}}$ & $2.40^{\mathrm{ns}}$ & $20.32^{*}$ & $27.52^{*}$ & $105.96^{*}$ & $5.28^{*}$ & $0.12^{\mathrm{ns}}$ & $7.97^{*}$ & $2.68^{\mathrm{ns}}$ \\
\hline C.C. & $7.62^{*}$ & $7.42^{*}$ & $7.02^{*}$ & $14.59^{*}$ & $2.80^{*}$ & $8.05^{*}$ & $4.58^{*}$ & $7.37^{*}$ & $7.71^{*}$ \\
\hline CV $(\%)$ & 30.08 & & & & & & & & \\
\hline S.T. & $80.48^{*^{-}}$ & - & - & - & - & - & - & - & - \\
\hline C.C. $\times$ S.T. & $2.59^{*}$ & - & - & - & - & - & - & - & - \\
\hline CV (\%) & 24.67 & & & & & & & & \\
\hline Total & 219 & & & & & & & & \\
\hline
\end{tabular}

Note. C.C.: cover crops; CV: coefficient of variation; S.T.: sampling time; DM: dry mass; N: nitrogen; P: phosphorus; $\mathrm{K}^{+}$: potassium; $\mathrm{Ca}^{2+}$ : calcium; $\mathrm{Mg}^{2+}$ : magnesium; $\mathrm{Fe}^{3+}$ : iron; Mn: manganese; $\mathrm{Zn}^{2+}$ : zinc.

* Significant $(\mathrm{p}<0.05)$; ns: not significant $(\mathrm{p}>0.05)$.

The overall mean of DM production was $7.4 \mathrm{Mg} \mathrm{ha}^{-1}$ (except for Crotalaria juncea, which presented the greatest 
yield). The Pennisetum glaucum + Crotalaria spectabilis intercropping presented the lowest DM production. It is probably related to the competition for natural resources such as light, since Crotalaria spectabilis presents faster establishment and higher initial growth rate than Pennisetum glaucum (Table 3). The DM in this treatment was lower than $6.0 \mathrm{tha}^{-1}$, which is the minimum required to obtain a good soil cover rate, according to Alvarenga et al. (2001). On the other hand, some studies performed in Cerrado biome have considered this amount of straw low, which provides insufficient carbon input into the soil. Therefore, it is recommended to produce a larger amount of dry straw mass, from 11.7 to $13.3 \mathrm{Mg} \mathrm{ha}^{-1}$ (Sá et al., 2015).

Crotalaria juncea presented the highest DM production $\left(12.5 \mathrm{Mg} \mathrm{ha}^{-1}\right)$. It was expected due to its size and to the high content of lignin and cellulose in its tissues, which provide higher amount of DM.

Similar values of DM in Crotalaria juncea (approximately $12 \mathrm{Mg} \mathrm{ha}^{-1}$ of DM) were found in the Central West (Padovan et al., 2015). Such production was attributed to the higher rainfall during the crop's development. The same justification can be used in the present work (Figure 1). However, in the Central West region of Brazil, Pittelkow et al. (2012) observed a production of $8.9 \mathrm{Mg} \mathrm{ha}^{-1}$. The DM production of the same cover crop species can vary according to the location, climatic conditions, temperature, rainfall, soil fertility, and crop cycle (Pissinati et al., 2018).

Table 3. Production of dry mass (DM) and $\mathrm{C} / \mathrm{N}$ ratio of the cover crops used in the study

\begin{tabular}{lll}
\hline Cover Plants & $\mathrm{DM}\left(\mathrm{Mg} \mathrm{ha}^{-1}\right)$ & Ratio C/N \\
\hline Crotalaria juncea & $12.5 \mathrm{a}$ & 32 \\
Crotalaria spectabilis & $7.3 \mathrm{~b}$ & 26 \\
Crotalaria ochroleuca & $7.9 \mathrm{~b}$ & 25 \\
Cajanus cajan -cv. Iapar 43 & $7.5 \mathrm{~b}$ & 19 \\
Cajanus cajan -cv. IAC-Fava larga & $8.7 \mathrm{~b}$ & 25 \\
Mucuna aterrima & $6.6 \mathrm{c}$ & 17 \\
Brachiaria ruziziensis & $8.3 \mathrm{~b}$ & 29 \\
Pennisetum glaucum & $7.9 \mathrm{~b}$ & 30 \\
Pennisetum glaucum + C. spectabilis & $5.6 \mathrm{c}$ & 28 \\
Pennisetum glaucum + C. ochroleuca & $7.5 \mathrm{~b}$ & 28 \\
Mean & 8.1 & \\
\hline
\end{tabular}

Note. Mean values with the same letter in the column did not differ by the Scott-knott test $(\mathrm{p}<0.05) .{ }^{*}$ The $\mathrm{C} / \mathrm{N}$ ratio data were obtained for the purpose of characterizing the different cover plants.

Differences were observed for N, Ca and Fe contents (Table 4) in the shoot part of the plants. The concentration of $\mathrm{N}$ ranged from $20.7 \mathrm{~g} \mathrm{~kg}^{-1}$ to $43.4 \mathrm{~g} \mathrm{~kg}^{-1}$. The highest levels of $\mathrm{N}$ were observed in Crotalaria spectabilis, followed by Mucuna aterrima, Cajanus cajan (cv. IAC̃-Fava larga), Crotalaria ochroleuca and Cajanus cajan (cv. IAPAR 43) (Table 4).

Table 4. Nutrient contents in the aboveground mass of the cover plants used in the study

\begin{tabular}{|c|c|c|c|c|c|c|c|c|}
\hline \multirow{2}{*}{ Cover Crops } & \multicolumn{5}{|c|}{ Macronutrients } & \multicolumn{3}{|c|}{ Micronutrients } \\
\hline & $\mathrm{N}$ & $\mathrm{P}$ & $\mathrm{K}^{+}$ & $\mathrm{Ca}^{2+}$ & $\mathrm{Mg}^{2+}$ & $\mathrm{Fe}^{3+}$ & $\mathrm{Mn}$ & $\mathrm{Zn}^{2+}$ \\
\hline & \multicolumn{5}{|c|}{ 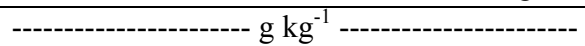 } & \multicolumn{3}{|c|}{----- $\mathrm{mg} \mathrm{kg}^{-1}$} \\
\hline Crotalaria juncea & $22.0 \mathrm{~b}$ & 4.0 & 12.0 & $26.9 \mathrm{a}$ & 4.2 & $141 \mathrm{c}$ & 39.3 & 32.9 \\
\hline Crotalaria spectabilis & $43.4 \mathrm{a}$ & 4.0 & 13.9 & $37.9 \mathrm{a}$ & 4.5 & $277 \mathrm{a}$ & 50.9 & 45.1 \\
\hline Crotalaria ochroleuca & $40.0 \mathrm{a}$ & 4.0 & 14.2 & $3.4 \mathrm{~b}$ & 4.8 & $206 \mathrm{~b}$ & 45.8 & 38.2 \\
\hline Cajanus cajan - cv. Iapar 43 & $34.6 \mathrm{a}$ & 3.9 & 9.9 & $27.9 \mathrm{a}$ & 4.6 & $225 \mathrm{~b}$ & 43.8 & 50.5 \\
\hline Cajanua cajan-cv. IAC-Fava larga & $41.7 \mathrm{a}$ & 3.8 & 12.3 & $24.2 \mathrm{a}$ & 4.6 & $228 \mathrm{~b}$ & 45.4 & 43.3 \\
\hline Mucuna aterrima & $40.2 \mathrm{a}$ & 3.9 & 11.4 & $12.9 \mathrm{~b}$ & 3.2 & $240 \mathrm{~b}$ & 54.9 & 48.2 \\
\hline Brachiaria ruziziensis & $29.9 \mathrm{~b}$ & 2.7 & 13.9 & $22.6 \mathrm{a}$ & 4.4 & $289 \mathrm{a}$ & 50.8 & 50.6 \\
\hline Pennisetum glaucum & $20.7 \mathrm{~b}$ & 3.7 & 11.2 & $22.1 \mathrm{a}$ & 3.5 & $237 \mathrm{~b}$ & 43.2 & 45.2 \\
\hline Pennisetum glaucum $+C$. spectabilis & $26.3 \mathrm{~b}$ & 3.8 & 14.1 & $21.8 \mathrm{a}$ & 4.2 & $370 \mathrm{a}$ & 37.8 & 43.2 \\
\hline Pennisetum glaucum + C. ochroleuca & $25.6 \mathrm{~b}$ & 3.6 & 15.1 & $27.1 \mathrm{a}$ & 3.9 & $141 \mathrm{c}$ & 51.7 & 51.4 \\
\hline
\end{tabular}

Note. N: nitrogen; P: phosphorus; $\mathrm{K}^{+}$: potassium; $\mathrm{Ca}^{2+}$ : calcium; $\mathrm{Mg}^{2+}$ : magnesium; $\mathrm{Fe}^{3+}$ : iron; Mn: manganese; $\mathrm{Zn}^{2+}$ : zinc. Mean values with the same letter in the column did not differ by the Scott-knott test $(\mathrm{p}<0.05)$. 
Crotalaria juncea presented the lowest concentrations of $\mathrm{N}\left(22.0 \mathrm{~g} \mathrm{~kg}^{-1}\right)$ among fabaceae species. This is related to the high content of fiber and lignin in this species. Tall Fabaceae cover crops present tissues with higher contents of $\mathrm{C}$ and lignin and tend to have lower $\mathrm{N}$ concentration than short height species (Pissinati et al. 2018).

In contrast, Crotalaria spectabilis presented the highest $\mathrm{N}$ content in the plant tissue $\left(43.4 \mathrm{~g} \mathrm{~kg}^{-1}\right)$ which is related to the lower $\mathrm{C} / \mathrm{N}$ ratio of this species (Table 3). These results confirm the efficiency of legumes in fixing atmospheric $\mathrm{N}$. The $\mathrm{N}$ fixed by the cover plants will be immobilized in the plant material and gradually released to the succession crop. Concentrations of $\mathrm{P}, \mathrm{K}, \mathrm{Mg}, \mathrm{Mn}$ and $\mathrm{Zn}$ in shoot were similar among treatments (Table 4) There was a difference in the Ca concentration with the highest values in Crotalaria spectabilis $\left(38 \mathrm{~g} \mathrm{~kg}^{-1}\right)$ and lowest in Crotalaria ochroleuca $\left(3.0 \mathrm{~g} \mathrm{~kg}^{-1}\right)$. Regarding micronutrients, there were differences among the species only for Fe (Table 4).

The accumulation of nutrients as a function of DM was significant for $\mathrm{N}, \mathrm{P}, \mathrm{K}$ and Ca contents and not significant for $\mathrm{Mg}$ (Table 5).

Table 5. Accumulation of macronutrients in the dry matter of the aboveground mass of cover plants used in the study

\begin{tabular}{|c|c|c|c|c|c|}
\hline Cover Plants & $\mathrm{N}$ & $\mathrm{P}$ & $\mathrm{K}^{+}$ & $\mathrm{Ca}^{2+}$ & $\mathrm{Mg}^{2+}$ \\
\hline & \multicolumn{5}{|c|}{------------------------------------------ $\mathrm{kg} \mathrm{ha}^{-1}$} \\
\hline Crotalaria juncea & $274 \mathrm{a}$ & $49.7 \mathrm{a}$ & $151 \mathrm{a}$ & $335 \mathrm{a}$ & 52.3 \\
\hline Crotalaria spectabilis & $316 \mathrm{a}$ & $30.1 \mathrm{~b}$ & $108 \mathrm{a}$ & $269 \mathrm{a}$ & 34.6 \\
\hline Crotalaria ochroleuca & $315 \mathrm{a}$ & $31.2 \mathrm{~b}$ & $111 \mathrm{a}$ & $25 \mathrm{c}$ & 37.2 \\
\hline Cajanus cajan-cv. Iapar 43 & $260 \mathrm{a}$ & $29.4 \mathrm{~b}$ & $75 \mathrm{~b}$ & $210 \mathrm{~b}$ & 34.4 \\
\hline Cajanua cajan-cv. IAC-Fava larga & $363 \mathrm{a}$ & $32.6 \mathrm{~b}$ & $105 \mathrm{a}$ & $208 \mathrm{~b}$ & 40.9 \\
\hline Mucuna aterrima & $269 \mathrm{a}$ & $25.6 \mathrm{~b}$ & $75 \mathrm{~b}$ & $86 \mathrm{c}$ & 21.0 \\
\hline Brachiaria ruziziensis & $253 \mathrm{a}$ & $22.9 \mathrm{~b}$ & $118 \mathrm{a}$ & $183 \mathrm{~b}$ & 36.6 \\
\hline Pennisetum glaucum & $163 \mathrm{~b}$ & $29.6 \mathrm{~b}$ & $89 \mathrm{~b}$ & $174 \mathrm{~b}$ & 27.8 \\
\hline Pennisetum glaucum + C. spectabilis & $144 \mathrm{~b}$ & $21.3 \mathrm{~b}$ & $78 \mathrm{~b}$ & $124 \mathrm{c}$ & 23.5 \\
\hline Pennisetum glaucum + C. ochroleuca & $188 \mathrm{~b}$ & $29.2 \mathrm{~b}$ & $112 \mathrm{a}$ & $205 \mathrm{~b}$ & 30.0 \\
\hline
\end{tabular}

Note. $\mathrm{N}$ : nitrogen; $\mathrm{P}$ : phosphorus; $\mathrm{K}^{+}$: potassium; $\mathrm{Ca}^{2+}$ : calcium; $\mathrm{Mg}^{2+}$ : magnesium. Mean values with the same letter in the column, did not differ by the Scott-knott test $(\mathrm{p}<0.05)$.

Cajanus cajan (cv. IAC-Fava larga) showed the highest amount of total $\mathrm{N}$ extracted (363 $\left.\mathrm{kg} \mathrm{ha}^{-1}\right)$, followed by Crotalaria spectabilis $\left(316 \mathrm{~kg} \mathrm{ha}^{-1}\right)$ and Crotalaria ochroleuca $\left(315 \mathrm{~kg} \mathrm{ha}^{-1}\right)$ which did not differ statistically from Crotalaria juncea $\left(274 \mathrm{~kg} \mathrm{ha}^{-1}\right)$, Brachiaria ruziziensis $\left(253 \mathrm{~kg} \mathrm{ha}^{-1}\right)$ and Mucuna aterrima $\left(269 \mathrm{~kg} \mathrm{ha}^{-1}\right)$ (Table 5). Cavalcante et al. (2012) also verified greater $\mathrm{N}$ input with Cajanus cajan (fava larga). Cajanus cajan (cv. IAC-Fava larga) also recycled considerable amounts of $\mathrm{P}, \mathrm{K}$ and $\mathrm{Ca}$. In the present study, $\mathrm{N}$ values were similar to those found by Pissinati et al. (2018), which reported $\mathrm{N}$ input between 168 and $473 \mathrm{~kg} \mathrm{ha}^{-1}$ in the Central West region of Brazil.

The amount of total $\mathrm{N}$ in the biomass of Pennisetum glaucum indicates that although it is not a fabacea, it accumulates and recycles a considerable amount of $\mathrm{N}\left(163 \mathrm{~kg} \mathrm{ha}^{-1}\right)$, followed by $\mathrm{K}$ and Ca with higher amounts of biomass (Table 5). The content of K accumulated by Pennisetum glaucum ( $89 \mathrm{~kg} \mathrm{ha}^{-1}$, Table 5) is within the range observed by other authors in the Cerrado, which was from 53 to $115 \mathrm{~kg} \mathrm{ha}^{-1}$ (Pacheco et al., 2013).

Pennisetum glaucum stands out due to the ability of extracting $\mathrm{N}$ and $\mathrm{K}$ from the soil and accumulating them in its tissue, favoring the cycling for the following crops (Pacheco et al., 2017). In addition, it has already been used in the Cerrado region of Piauí due to its rusticity and high tolerance to water stress and it has demonstrated efficiency when followed by soybean crop, in the production of biomass and nutrient cycling (Pacheco et al., 2017).

The accumulation of $\mathrm{P}$ was very similar, with higher amount in Crotalaria juncea $\left(49.7 \mathrm{~kg} \mathrm{ha}^{-1}\right) \mathrm{which}^{\mathrm{s}}$ accumulated from $21.3 \mathrm{~kg} \mathrm{ha}^{-1}$ to $32.6 \mathrm{~kg} \mathrm{ha}^{-1} \mathrm{P}$ (Table 5).

Crotalaria juncea, Crotalaria spectabilis, Crotalaria ochroleuca, Cajanus cajan (cv. IAC-Fava larga), Brachiaria ruziziensis and Pennisetum glaucum + Crotalaria ochroleuca intercropping, presented the highest accumulations of $\mathrm{K}$ ranging from 112 to $151 \mathrm{~kg} \mathrm{ha}^{-1}$. The lowest accumulation was in the Cajanus cajan (cultivar 
IAPAR 43) with $74.63 \mathrm{~kg} \mathrm{ha}^{-1}$. The use of cover crops should be planned to straw production and/or nutrient cycling. Using species that prioritize the straw production is necessary to make the NT system viable. Then, the treatments which presented low decomposition deserve special attention, since they maintained a low DM reduction until the end of the evaluation, 314 days after the management (DAM) (Figure 2). These treatments were: the Pennisetum glaucum + Crotalaria spectabilis, Pennisetum glaucum + Crotalaria ochroleuca intercroppings, and the single Cajanus cajan (cv. IAPAR 43), Crotalaria ochroleuca, Cajanus cajan (cv. IAC-Fava Larga) and Pennisetum glaucum, with half life time of 407, 346, 330, 315 and 301 days, respectively (Figure 2). Except Cajanus cajan (cv. IAPAR 43), whose plant residues presented a C/N ratio equal to 19. For the other treatments $\mathrm{C} / \mathrm{N}$ ratio was equal to or greater than 25 (Table 2), which justifies the lower decomposition rate (Teixeira et al., 2012).

The intercropping use allows the inclusion of species which can be an alternative to no-tillage systems. According to Cavalli et al. (2018) the satisfactory performance of intercropping system is because of the complementarity between the different species. Fabaceae, for example, promote $\mathrm{N}$ biological fixation, making this nutrient available in the soil and consequently favoring the development of poaceae, which will later support its growth.

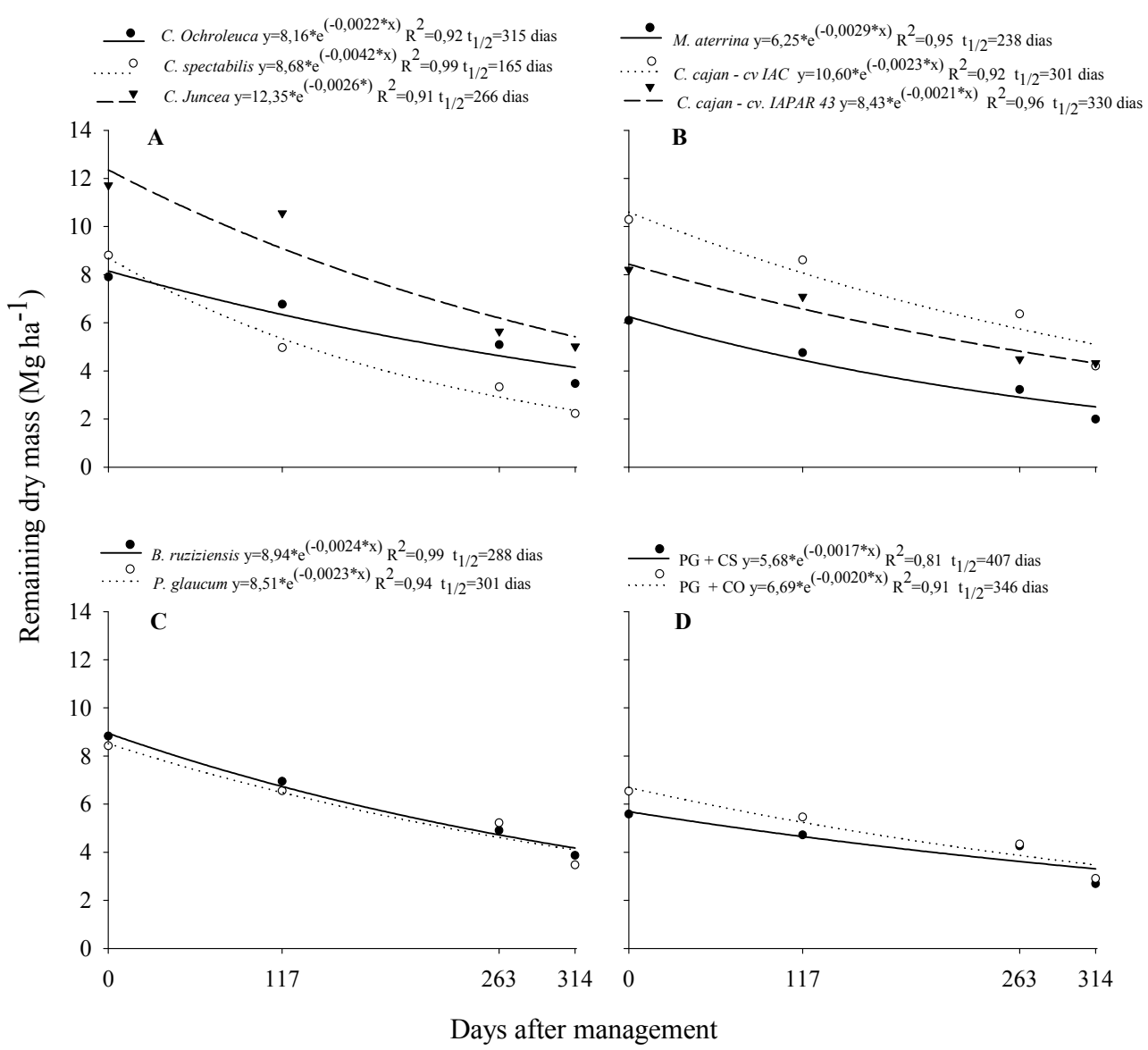

Figure 2. Remaining dry mass of cover crops after desiccation. PG + CS: Pennisetum glaucum + Crotalaria spectabilis intercropping; PG + CO: Pennisetum glaucum + Crotalaria ochroleuca intercropping

The reduction of the decomposition rate in the intercropping residues allows the permanence of crop residues on the soil longer and contributes to the maintenance of soil moisture, protection of the soil surface against the raindrop impact, formation of crusts (Dalla Rosa et al., 2017) and erosive processes (Bertol et al., 2017). In addition, the presence of Pennisetum glaucum in the mixed crop may have favored the remaining residues on the soil and the lower rate of decomposition. Approximately $40 \%$ of the accumulated phytomass of Pennisetum glaucum is from the stem, which consists of lignified tissues with a higher $\mathrm{C} / \mathrm{N}$ ratio than the leaves, which favors the lower decomposition rate, contributing to the longer permanence of these residues (Pissinati et al. 
2018). This fact was observed in this study with the use of Pennisetum glaucum + Crotalaria spectabilis. Despite being the treatment with the lowest DM production (5.6 $\mathrm{Mg} \mathrm{ha}^{-1}$, Table 3), it was also the one with the lowest decomposition rate and which kept the surface covered for a longer period.

The species that presented the greatest decomposition were: Crotalaria spectabilis and Mucuna aterrima with $1 / 2$ life time of 165 and 238 DAM, respectively. These species presented an average DM production of $6.8 \mathrm{Mg} \mathrm{ha}^{-1}$. However, despite the good DM production, they also presented a very fast decomposition rate (Figure 2).

The decomposition rate is not only related to the $\mathrm{C} / \mathrm{N}$ ratio, since Crotalaria spectabilis presented a higher $\mathrm{C} / \mathrm{N}$ ratio (26) than Mucuna aterrima (17), but also showed the highest decomposition rate. In addition to the $\mathrm{C} / \mathrm{N}$ ratio, lignin, polyphenol and chemical composition are factors that affect the decomposition rate in cover crops (Lima Filho et al. 2014). These characteristics along with the stage of development at desiccation time (Padovan et al., 2015) and the climatic conditions during the evaluated period (Collier et al., 2018) show the ability of each species to maintain the cover on the soil.

Regarding relative losses of DM, the following decreasing order of decomposition was established at 314 days after desiccation: i) poaceae: Brachiaria ruziziensis $(83 \%)>$ Pennisetum glaucum (81\%); ii) fabaceae: Crotalaria spectabilis $(95 \%)>$ Mucuna aterrima $(88 \%)>$ Crotalaria juncea $(85 \%)$, Cajanus cajan (cv. IAC-Fava larga) (81\%), Crotalaria ochroleuca and Cajanus cajan (cv. IAPAR 43) (79\%); and iii) intercropping systems: Pennisetum glaucum + Crotalaria ochroleuca (76\%) and Pennisetum glaucum + Crotalaria spectabilis (71\%).

All the evaluated species presented potential to be used in crop rotation systems, making no-tillage system viable in the Cerrado region of Piauí. However, it is recommended to select species according to specific purposes (nutrient cycling or dry mass production).

Knowing the temporal dynamics of DM accumulation and decomposition of the different cover crops is important to manage the agricultural systems in Cerrado. It is also necessary to choose the correct species to be used and the ideal moment to sown the following crop so the decomposition and release of nutrients by the cover plants can happen in the period of greater demand by the following crop. Therefore, for having a no-tillage system, it is necessary to have a high mass production to cover the soil surface and low decomposition rate.

\section{Conclusion}

The studied cover crops have potential to be used in crop rotation in no-tillage system in the Cerrado of Piauí, with the highest dry mass yield obtained with Crotalaria juncea, Cajanus cajan (cv. IAC-Fava larga), Pennisetum glaucum and Brachiaria ruziziensis.

The greatest accumulation of nutrients was obtained in Crotalaria juncea, Crotalaria spectabilis, Cajanus cajan (cultivar IAPAR 43), Cajanus cajan (cv. IAC-Fava larga) and Mucuna aterrima.

Plant residues of Mucuna aterrima and Crotalaria spectabilis showed faster decomposition. In contrast, the intercropping systems Pennisetum glaucum + Crotalaria spectabilis and Pennisetum glaucum + Crotalaria ochroleuca remained longer on the soil surface.

\section{References}

Alvarenga, R. C., Cabezas, W. A. L., Cruz, J. C., \& Santana, D. P. (2001). Plantas de cobertura de solo para sistema plantio direto. Informe Agropecuário, 22, 25-36.

Alvares, C. A., Stape, J. L., Sentelhas, P. C., Moraes, G., Leonardo, J., \& Sparovek, G. (2013). Köppen's climate classification map for Brazil. Meteorol Z., 22(6), 711-728. https://doi.org/10.1127/0941-2948/2013/0507

Barbosa Borges, W. L. B., de Freitas, R. S., Mateus, G. P., de Sá, M. E., \& Alves, M. C. (2015). Produção de soja e milho cultivados sobre diferentes coberturas. Revista Ciência Agronômica, 46(1), 89-98. https://doi.org/ $10.1590 / \mathrm{S} 1806-66902015000100011$

Berg, B. (2018). Decomposing litter; limit values; humus accumulation, locally and regionally. Applied Soil Ecology, 123, 494-508. https://doi.org/10.1016/j.apsoil.2017.06.026

Bertol, I., Schick, J., Bandeira, D. H., Paz-Ferreiro, J., \& Vázquez, E. V. (2017). Multifractal and joint multifractal analysis of water and soil losses from erosion plots: a case study under subtropical conditions in Santa Catarina highlands, Brazil. Geoderma, 287, 116-125. https://doi.org/10.1016/j.geoderma.2016.08.008

Cavalcante, V. S., Santos, V. R., dos Santos Neto, A. L., dos Santos, M. A., dos Santos, C. G., \& Costa, L. C. (2012). Biomassa e extração de nutrientes por plantas de cobertura. Revista Brasileira de Engenharia Agricola e Ambiental, 16(5), 521-529. https:// doi: 10.1590/S1415-43662012000500008 
Cavalli, E., Lange, A., Cavalli, C., \& Behling, M. (2018). Decomposition and release of nutrients from crop residues on soybean-maize cropping systems. Brazilian Journal of Agricultural Sciences/Revista Brasileira de Ciências Agrárias, 13(2). https://doi.org/10.5039/agraria.v13i2a5527

Collier, L. S., Arruda, E., Campos, L. F. C., \& Nunes, J. N. V. (2018). Soil chemical attributes and corn productivity grown on legume stubble in agroforestry systems. Revista Caatinga, 31(2), 279-289. https://doi.org/10.1590/1983-21252018v31n203rc

Dalla Rosa, J., Cooper, M., Darboux, F., Medeiros, J. C., Campanaro, C., \& Pinto, L. R. M. (2017). Influence of crust formation on soil porosity under tillage systems and simulated rainfall. Hydrology, 4, 3-10. https://doi.org/10.3390/hydrology4010003

Ferreira, A. O., Amado, T., Rice, C. W., Diaz, D. A. R., Keller, C., \& Inagaki, T. M. (2016). Can no-till grain production restore soil organic carbon to levels natural grass in a subtropical Oxisol. Agriculture, Ecosystems \& Environment, 229, 13-20. https://doi.org/10.1016/j.agee.2016.05.016

Ferreira, D. F. (2011). Sisvar: A computer statistical analysis system. Cien Agrotec, 35(6), 1039-1042. https://doi.org/10.1590/S1413-70542011000600001

Fontana, A., Teixeira, W. G., de Carvalho Balieiro, F., de Moura, T. P. A., de Menezes, A. R., \& Santana, C. I. (2016). Características e atributos de Latossolos sob diferentes usos na região Oeste do Estado da Bahia. Pesquisa Agropecuária Brasileira, 51(9), 1457-1465. https://doi.org/10.1590/s0100-204x2016000900044

Krenchinski, F. H., Cesco, V. J. S., Rodrigues, D. M., Albrecht, L. P., Wobeto, K. S., \& Albrecht, A. J. P. (2018). Desempenho agronômico de soja cultivada em sucessão a espécies de cobertura de inverno. Pesquisa Agropecuária Brasileira, 53(8), 909-917. https://doi.org/10.1590/s0100-204x2018000800005

Lima Filho, O. F., Ambrosano, E. J., Rossi, R., \& Carlos, J. A. D. (2014). Adubação verde e plantas de cobertura no Brasil: Fundamentos e prática (p. 478). Embrapa, Brazil.

Nielsen, D. C., Lyon, D. J., Higgins, R. K., Hergert, G. W., Holman, J. D., \& Vigil, M. F. (2016). Cover crop effect on subsequent wheat yield in the Central Great Plains. Agronomy Journal, 108(1), $243-256$. https://doi.org/10.2134/agronj2015.0372

Olson, J. S. (1963). Energy storage and the balance of producers and decomposers in ecological systems. Ecology, 44(2), 322-331. https://doi.org/10.2307/1932179

Pacheco, L. P., Martins de Sousa Monteiro, M., Fonseca da Silva, R., dos Santos Soares, L., Lima Fonseca, W., Azevedo Nóbrega, J. C., \& Anteveli Osajima, J. (2013). Produção de fitomassa e acúmulo de nutrientes por plantas de cobertura no cerrado piauiense. Bragantia, 72(3). https://doi.org/10.1590/brag.2013.041

Pacheco, L. P., Monteiro, M., de Sousa, M. A. R. T. I. N. S., Petter, F. A., Nóbrega, J. C. A., \& Santos, A. S. D. (2017). Biomass and nutrient cycling by cover crops in Brazilian Cerrado in the state of Piaui. Revista Caatinga, 30(1), 13-23. https://doi.org/10.1590/1983-21252017v30n102rc

Padovan, M. P., Carneiro, L. F., Moitinho, M. R., Felisberto, G., Carneiro, D. N. M., \& de Sá Motta, I. (2015). Dinâmica de Acúmulo de Massa e Nutrientes pela Crotalaria juncea para Fins de Adubação Verde e o Estádio Adequado para seu Manejo. Cadernos de Agroecologia, 9(4), 1-12.

Pavinato, P. S., Rodrigues, M., Soltangheisi, A., Sartor, L. R., \& Withers, P. J. A. (2017). Effects of cover crops and phosphorus sources on maize yield, phosphorus uptake, and phosphorus use efficiency. Agronomy Journal, 109(3), 1039-1047. https://doi.org/10.2134/agronj2016.06.0323

Pissinati, A., Moreira, A., \& Santoro, P. H. (2018). Yield components and nutrients content in summer cover plants used in crop rotation in no-tillage system. Communications in Soil Science and Plant Analysis, 14, 1-13. https://doi.org/10.1080/00103624.2018.1474899

Pittelkow, F. K., Scaramuzza, J. F., dos Santos Weber, O. L., Maraschin, L., de Assis Valadão, F. C., \& dos Santos Oliveira, E. (2012). Produção de biomassa e acúmulo de nutrientes em plantas de cobertura sob diferentes sistemas de preparo do solo. Agrarian, 5(17), 212-222.

Qu, L., Huang, Y., Ma, K., Zhang, Y., \& Biere, A. (2016). Effects of plant cover on properties of rhizosphere and inter-plant soil in a semiarid valley, SW China. Soil Biology and Biochemistry, 94, 1-9. https://doi.org/ 10.1016/j.soilbio.2015.11.004 
Sá, J. C. M, Séguy, L., Tivet, F., Lal, R., Bouzinac, S., Borszowskei, P. R., \& Rosa, J. (2015). Carbon depletion by plowing and its restoration by no-till cropping systems in Oxisols of subtropical and tropical agro-ecoregions in Brazil. Land Degradation \& Development, 26(6), 531-543. https://doi.org/10.1002/ ldr. 2218

Sousa, D. C., Medeiros, J. C., Dalla Rosa, J., Lacerda, J. J. J., Mafra, A. L., \& de Sousa Mendes, W. (2017). Chemical attributes of agricultural soil after the cultivation of cover crops. Aust. J. Crop. Sci, 11, 1497-1503.

Sousa, D. D., \& Lobato, E. (2004). Cerrado: Correção do solo e adubação (p. 416). Planaltina: Embrapa Cerrados.

Teixeira, M. B., Loss, A., Gervásio Pereira, M., \& Pimentel, C. (2012). Decomposição e ciclagem de nutrientes dos resíduos de quarto plantas de cobertura do solo. Idesia (Arica), 30(1), 55-64. https://doi.org/10.4067/ S0718-34292012000100007

Tiecher, T., Santos, D. R., \& Calegari, A. (2012). Soil organic phosphorus forms under different soil management systems and winter crops, in a long term experiment. Soil and Tillage Research, 124, 57-67. https://doi.org/10.1016/j.still.2012.05.001

Vitti, G. C., Ferreira, A. C., Braga, G., \& Gomes, M. T. B. (2002). Métodos de análises de elementos em material vegetal (p. 28). Piracicaba, Escola Superior de Agricultura Luiz de Queiroz.

Wider, R. K., \& Lang, G. E. (1982). A critique of the analytical methods used in examining decomposition data obtained from litter bags. Ecology, 63(6), 1636-1642. https://doi.org/10.2307/1940104

\section{Copyrights}

Copyright for this article is retained by the author(s), with first publication rights granted to the journal.

This is an open-access article distributed under the terms and conditions of the Creative Commons Attribution license (http://creativecommons.org/licenses/by/4.0/). 